\title{
10: 135229746-135241501
}

National Cancer Institute

\section{Source}

National Cancer Institute. 10:135229746-135241501. NCI Thesaurus. Code C42110.

Physical location of CYP2E1_Gene 